\title{
Chemical Treatment in Industrial Wastewater of Polyester Synthetic Fiber Made from Recycled Polyethylene Terephthalate Bottles: Minimize Environmental Impacts
}

\author{
Y. Setiawan*, A. Taufik Rizaludin, M. Nur Aini, S. Saepuloh
}

Center for Pulp and Paper Jl. Raya Dayeuh Kolot No. 132 Bandung, West Java Province, Indonesia

\section{PAPER INFO}

Paper history:

Received 02 December 2020

Accepted in revised form 08 July 2021

\section{Keywords:}

Polyethylene Terephthalate Bottle Waste

Polyester Synthetic Fiber

Wastewater

Coagulant

Flocculant

\begin{abstract}
A B S T RACT
The polyester synthetic fiber (PSF) industry has recycled polyethylene terephthalate (PET) bottle into raw material and converted them into economically valuable textile materials. This study was aimed to provide an overview of wastewater treatment from PSF industry in minimizing its impact on the environment. The study of wastewater treatment from PSF industry has been carried out in chemical-physical treatments. The Jar Test experiment has been conducted with coagulant and flocculant addition into $1000 \mathrm{~mL}$ of wastewater inside a $1 \mathrm{~L}$ beaker glass. Wastewater was treated with 3 coagulants and flocculant doses varied in the range of poly aluminum chloride (PAC) $175-225 \mathrm{mg} / \mathrm{L}$ and PE $0.25 \mathrm{mg} / \mathrm{L}$. The results showed that the dose utilization of $200 \mathrm{mg} / \mathrm{L}$ of $5 \%$ PAC coagulant solution and $0.25 \mathrm{mg} / \mathrm{L}$ dose of $0.02 \%$ poly electrolyte (PE) flocculant solution could produce a treated wastewater that has complied with the effluent quality standards. The application of this optimum dose can reduce wastewater pollutants subtances of PSF industry which can minimize its impact on the environment.
\end{abstract}

doi: 10.5829/ijee. 2021.12.03.02

\section{INTRODUCTION1}

The world's population consumes one million plastic bottles in every minute. Large amounts of polyethylene terephthalate (PET) plastic bottle waste are disposes on the landfills every year. It has been reported that the annual world production rate of PET plastic were 41.56 and 73.36 millon tons in 2014 and 2020, repectively [1]. Plastic bottles are considered non-biodegradable waste because of their long decomposition time. Even if the amount of converted PET plastic bottles waste is less than $10 \%$, the iniciative of the textile industry to convert it into polyester fabrics nonetheless will help to protect our planet and future $[2,3]$.

After cleaning and treatment processes, the recycled PET plastic bottle waste may become new materials with economic value. At the recycling plant, Polyethylene Terephthalate (PET) bottle waste will be processed into dacron, strapping band, and geotextile materials. One of the recycled material results from PET bottle is polyester synthetic fiber (PSF) which has a resembling shape of synthetic cotton. This material will be marketed in three forms, namely solid fiber, hollow conjugate (HC), or hollow conjugate silicon (HCS) [4-6].

The PSF production process may consists of several stages including the washing process of the recycled PET plastic bottle to remove glue, paper labels, dirt and contained product. Washing process was carried out at an ambient temperature of $90^{\circ} \mathrm{C}$ for 12 minutes. Detergent and $\mathrm{NaOH}$ were usually utilized as washing solution to remove dirt, oil and protein. Clean PET plastic bottles are then chopped into small flakes and dried. The drying process of PET bottle flakes was conducted to reduce moisture content into a maximum of $2 \%$. Dye, brightening optical and titanium dioxide were added in this process, to make PET bottle flakes visibly look brighter and cleaner. The dry PET flakes were then spun. The spinning process begun with transferring the PET 
bottle flakes from the fill hopper to the screw extruder. In the screw extruder, PET bottle flakes were heated, melted and pressed through a spinerete which will produces plastic fiber filaments. The plastic fiber filaments were sprayed with water to prevent sticking to each other and then cut with a blade [2, 5-8].

PSF industry is usually equipped with production support facilities, such as boilers and oil heaters to support the heat washing process, the spinning process, and the wastewater treatment plant [5]. In the plastic recycling process, wastewater containing high concentrations of COD was produced which must be treated first before being discharged into the environment. Wastewater effluent discharged into the environment/water body must follow the effluent quality standard requirements for textile industry wastewater based on the Regulation of the Minister of Environment and Forestry of the Republic of Indonesia Number P.16/2019.

Wastewater treatment of PSF industry may be conducted through chemical treatment by a coagulationflocculation process. The coagulation process is a process of destabilizing particles using coagulants to form small agglomerates. Flocculation is a process in which particles formed as a consequence of destabilization to form a larger agglomerate. The coagulation-flocculation process is one of the best options for treating industrial wastewater. The coagulants are including aluminum sulfate, ferric chloride, lime, iron sulfate, and polyaluminum chloride (PAC). The coagulationflocculation process is considered as one of the methods of industrial wastewater treatment which is efficient in reducing the concentration of COD, TSS and color. The main advantage of chemical treatment process is that most of COD and TSS contents are reduced thus the secondary treatment will be more cost-effective [9-11]. The PAC polymer coagulant has a better ability to reduce wastewater pollutants, especially color parameter than the Aluminum Sulfate $\left(\mathrm{Al}_{2}\left(\mathrm{SO}_{4}\right)_{3}\right)$ coagulant because of its polymer form with long and branched chain thus may capture more colloid particles $[12,13]$. In addition, it is also more beneficial for the industry not only due to its cost minimization for reducing color and COD, but also for minimizing the environmental impact $[11,12,14,15]$.

Wastewater which causes surface water coloration is aesthetically undesirable and causes disruption of the aquatic biosphere due to sunlight penetration decrement and dissolved oxygen depletion. In addition, colored compounds also may contribute to the failure of biological wastewater treatment processes. Biological processing was generally less capable in reducing color, but the much more capable to reduce in BOD and COD. Therefore, the wastewater effluent from activated sludge, a biological treatment process, may still contains high color and COD content $[11,15]$. In addition, biological treatment/activated sludge, may takes high energy consumption, generates large amounts of sludge production, and raises operational problems including color, foaming, and bulking in secondary clarifiers $[9,10$, 12, 13].

Chemical wastewater treatment is usually operated using a sequential treatment combination of a coagulation process using a coagulant followed by a flocculation process using a flocculant. The main function of flocculants, which consisting of very high mass polyelectrolytes and usually cationic charges, is to collect small flocks into large flocks $[12,16]$. The wastewater chemical treatment process might serves as either single process of primary chemical treatment or as a pretreatment stage before biological treatment [17]. The coagulation process using lime at a dose of $1400 \mathrm{mg} / \mathrm{L}$ could reduce the turbidity of wastewater by $94 \%$, a decrease in COD by $86 \%$, a decrease in TSS by $93 \%$, a decrease in TDS by $78 \%$ and a decrease in color by $91.6 \%$ [18]. Wastewater treatment for washing recycling PET bottles with coagulation-flocculation treatment using 4 $\mathrm{mg} / \mathrm{L}$ of $\mathrm{FeCl}(4 \%)$ coagulant solution as much as and 0.8 $\mathrm{mg} / \mathrm{L}$ of Polyelectrolyte (PE) $(0.2 \%)$ flocculant solution, may reduce COD by $58.28 \%[19,20]$.

The study of chemical treatment for the wastewater of PSF industry is presented in this paper. The effect of coagulant and flocculant dose combinations on the quality of treated wastewater is also described. This study aims to provide an overview of wastewater treatment for PSF industry which raw material was PET plastic waste in minimizing the impact on the environment.

\section{MATERIAL AND METHODS}

The wastewater used in the experiment was wastewater from the PSF industry which is using recycled PET bottles as raw materials. The plant located in West Java Province, Indonesia, with wastewater discharge was $<100$ $\mathrm{m}^{3} /$ day. The chemicals used were $10 \%$ PAC solution as a coagulant and $0.02 \%$ cationic poly electrolyte (PE) solution as a flocculant.

The Jar Test experiment used $1000 \mathrm{~mL}$ of the target wastewater, which was put into a $1 \mathrm{~L}$ beaker glass with coagulants and flocculants addition. Wastewater was treated with 3 varity of coagulant and flocculant doses which are P1: $175 \mathrm{mg} / \mathrm{L} \mathrm{PAC}$ and $0.25 \mathrm{mg} / \mathrm{L} \mathrm{PE}$; P2: 200 $\mathrm{mg} / \mathrm{L}$ PAC and $0.25 \mathrm{mg} / \mathrm{L} \mathrm{PE}$; and P3: $225 \mathrm{mg} / \mathrm{L} \mathrm{PAC}$ and $0.25 \mathrm{mg} / \mathrm{L}$ PE. The process of coagulation of wastewater was carried out with a stirring rotation of 100 rpm for 2 minutes and the flocculation process was carried out with a stirring rotation of $40 \mathrm{rpm}$ for 15 minutes. After the flocculation process was complete, the stirring process was stopped and the resulting mixture of wastewater was left for about 2 hours for the sedimentation process, separating the treated wastewater and the sludge.

The quality of wastewater before and after being chemical treatment was analyzed by methods for the 
parameters of $\mathrm{BOD}_{5}$ (iodometric-titrimetric), $\mathrm{COD}$ (sealed digestion and spectrometric), TSS (filtrationgravimetric), Phenol (colorimetric), Chromium (Atomic Absorption Spectrometry), $\mathrm{NH}_{3}-\mathrm{N} \quad$ (distilationtitrimetric), Sulfide (ion-selective electrode), Oil and Grease ( $n$-Hexane extraction), $\mathrm{pH}$ (electrometric) and color (spectrophotometric) as per the American Public Health Association (APHA) standard methods [21].

\section{RESULTS AND DISCUSSION}

\section{Wastewater quality before treatment}

The quality of untreated wastewater that originated from the PSF industry which is using recycled PET plastic bottle is shown in Table 1. This PSF industry does not have an adequate wastewater treatment plant (WWTP) installed yet.

The $\mathrm{pH}$, phenol, chromium, ammonia and sulfide parameters have complied with the quality standards based on Regulation of the Minister of Environment and Forestry of the Republic of Indonesia Number P.16/2019 for the textile industry which produces wastewater with a discharge of $<100 \mathrm{~m}^{3} /$ day. However, other parameters such as parameters $\mathrm{BOD}_{5}, \mathrm{COD}$, TSS, oil, grease and color are still above the standard requirements. Before being released, PSF industry wastewater contains high levels of pollutants, both organic and inorganic compounds, as indicated by the COD, $\mathrm{BOD}_{5}$ and TSS parameters, which need to be treated first before being discharged into the environment to avoid negative impact on the environment. The quality of PSF industrial wastewater is slightly lower than that reported by Santos et.al. [22] which was PET bottle washing wastewater which has COD 750-983 mg/L, TSS 732-1136 mg/L and turbidity $280-330$ NTU. The turbidity and COD value co-

Table 1. Characterization of raw wastewater before treatment

\begin{tabular}{|c|c|c|c|}
\hline No. & Parameter & Concentration & $\begin{array}{l}\text { Effluent Quality } \\
\text { Standards (EQS) }\end{array}$ \\
\hline 1 & $\mathrm{BOD}_{5}, \mathrm{mg} / \mathrm{L}$ & 264 & 60 \\
\hline 2 & $\mathrm{COD}, \mathrm{mg} / \mathrm{L}$ & 579 & 150 \\
\hline 3 & $\mathrm{TSS}, \mathrm{mg} / \mathrm{L}$ & 269 & 50 \\
\hline 4 & Phenol, mg/L & 0.26 & 0.5 \\
\hline 5 & Chromium, mg/L & 0.05 & 1 \\
\hline 6 & $\begin{array}{c}\text { Ammonia } \\
\left(\mathrm{NH}_{3}-\mathrm{N}\right), \mathrm{mg} / \mathrm{L}\end{array}$ & 5.4 & 8 \\
\hline 7 & Sulfide $\left(\mathrm{S}^{2-}\right), \mathrm{mg} / \mathrm{L}$ & 0.06 & 0.3 \\
\hline 8 & $\begin{array}{c}\text { Oil and Grease, } \\
\mathrm{mg} / \mathrm{L}\end{array}$ & 4.4 & 3 \\
\hline 9 & $\mathrm{pH}$ & 6.8 & $6-9$ \\
\hline 10 & Color, Pt-Co & 345 & 200 \\
\hline 11 & Discharge, $\mathrm{m}^{3} /$ day & $<100$ & 100 \\
\hline
\end{tabular}

ntained in wastewater are influenced by the amount of surfactant used. From the results of the characterization, it may be seen that several parameters have not been able to comply the quality standards, namely: $\mathrm{BOD}_{5}, \mathrm{COD}$, TSS, and Color. The next study will discuss the four parameters with the addition of $\mathrm{pH}$ because it may affect the effectiveness of the coagulation-flocculation process.

\section{Effect of coagulant and flocculant doses treatment on} the quality of treated wastewater

The results of wastewater treatment with chemical treatment with the codes P-1, P-2 and P-3 for parameters of $\mathrm{pH}, \mathrm{COD}, \mathrm{BOD}_{5}, \mathrm{TSS}$ and color can be seen in Figures 1, 2, 3, 4 and 5, respectively. All of the treated wastewater with three doses variations has neutral $\mathrm{pH}$ value, which are in the range of 7.1-7.3. All of them are in the range of effluent standard requirements for $\mathrm{pH}$ which is $6-9$ (Figure 1).

The wastewater quality of all three treatment variations (P-1, P-2 and P-3), have complied with effluent quality standard requirements for COD parameters $<150$ $\mathrm{mg} / \mathrm{L}$ (Figure 2). However, wastewater quality with low-

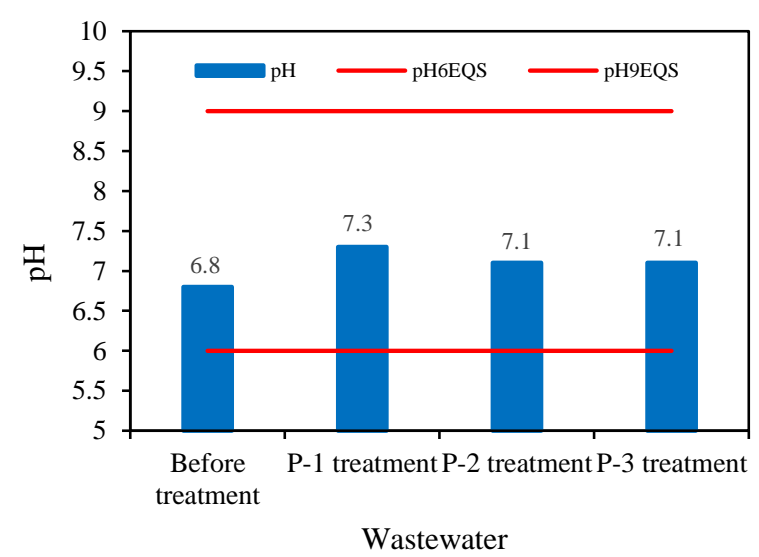

Figure 1. $\mathrm{pH}$ of wastewater before and after treatment

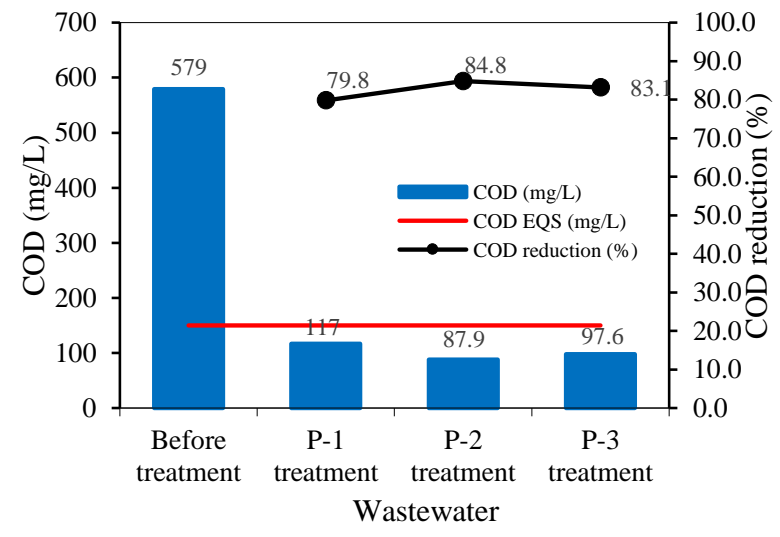

Figure 2. COD wastewater before and after treatment 
est COD value of $87.9 \mathrm{mg} / \mathrm{L}$ (and highest COD reduction: $84.5 \%$ ) may be obtained with P-2 treatment, which was using $200 \mathrm{mg} / \mathrm{L}$ of $5 \%$ Poly Aluminum Chloride (PAC) coagulant solution and $0.25 \mathrm{mg} / \mathrm{L}$ of $0.02 \%$ Poly Electrolyte (PE) flocculant solution.

All three treatment variations, could reduce $\mathrm{BOD}_{5}$ parameters by 92.7 - $93.1 \%$ from the untreated wastewater, with the remain concentration of $\mathrm{BOD}_{5}$ parameters for treated wastewater is around 18.2 - 19.3 $\mathrm{mg} / \mathrm{L}$, which already below the effluent quality standard for the $\mathrm{BOD}_{5}$ parameter, which is $<60 \mathrm{mg} / \mathrm{L}$ (Figure 3).

The TSS concentration of treated wastewater with $\mathrm{P}$ $1, \mathrm{P}-2$ and P-3 variations was already very low, which is around 5.4-7.5 $\mathrm{mg} / \mathrm{L}$, already far below the effluent quality standard for TSS parameters $<50 \mathrm{mg} / \mathrm{L}$ (Figure 4). The P-1, P-2 and P-3 treatment variations were able to reduce TSS concentrations by $97.2-98 \%$.

Wastewater treatment with P-1, P-2 and P-3 treatment variations could reduce color by $84 \%$ with a color value of $55 \mathrm{Pt}-\mathrm{Co}$. The color value of treated wastewater is already below the quality standard requirements for color parameters $<200 \mathrm{Pt}-\mathrm{Co}$ (Figure 5).

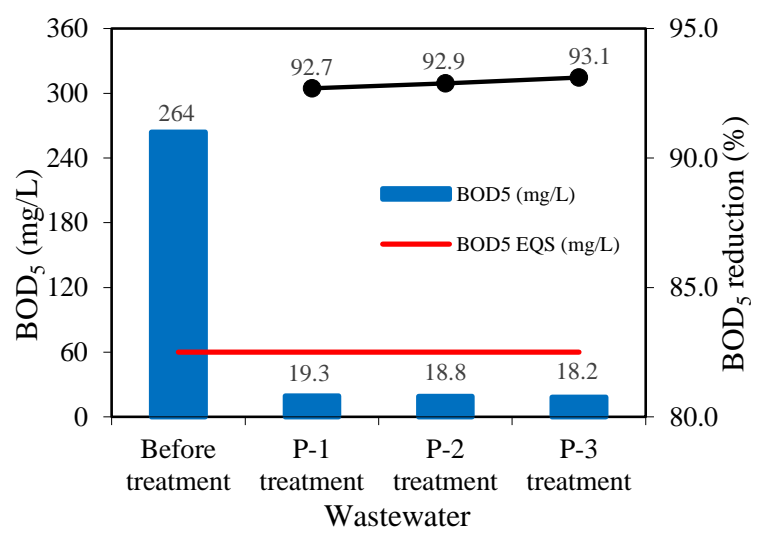

Figure 3. $\mathrm{BOD}_{5}$ wastewater before and after treatment

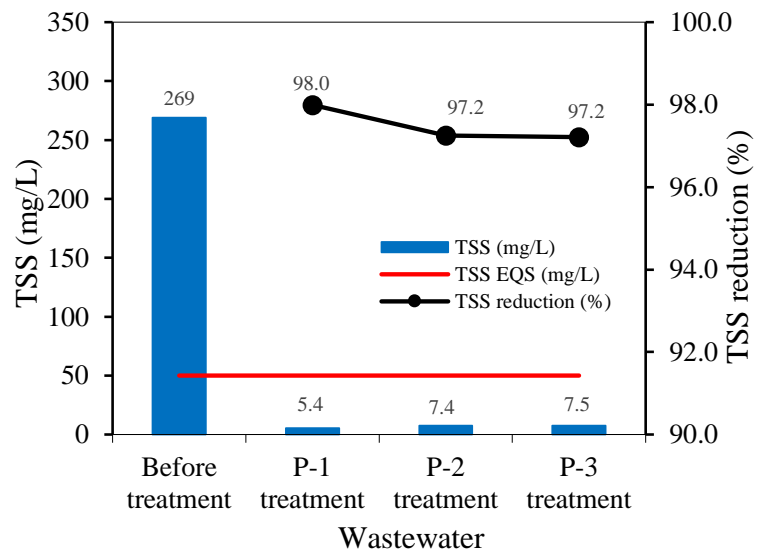

Figure 4. TSS of wastewater before and after treatment
When the color of untreated wastewater was compared to the treated wastewater, the comparison showed a big gap from brown color at the untreated wastewater, and clear color for the treated wastewater. Visually, the treated wastewater showed almost a comparable color with the color of tap water which has a color value of $28 \mathrm{Pt}-\mathrm{Co}$ (Figure 6).

This phenomenon occurs due to the entry of positively charged coagulant chemicals into wastewater containing negatively charged suspended solid particles. These negatively charged suspended solids are generally responsible for the coloration of wastewater. The ionic interaction between the positively charged coagulant chemicals and negatively charged suspended solid particles, destabilization occurs which could precipitate. This phenomenon could be described at Figure 7.

From the description above, it seems that the wastewater from P-2 treatment variation which using doses of $200 \mathrm{mg} / \mathrm{L}$ of $5 \%$ poly aluminum chloride (PAC) coagulant solution and $0.25 \mathrm{mg} / \mathrm{L}$ of $0.02 \%$ poly electrolyte (PE) flocculant solution, showed an optimum treated wastewater quality from all three treatment variat-

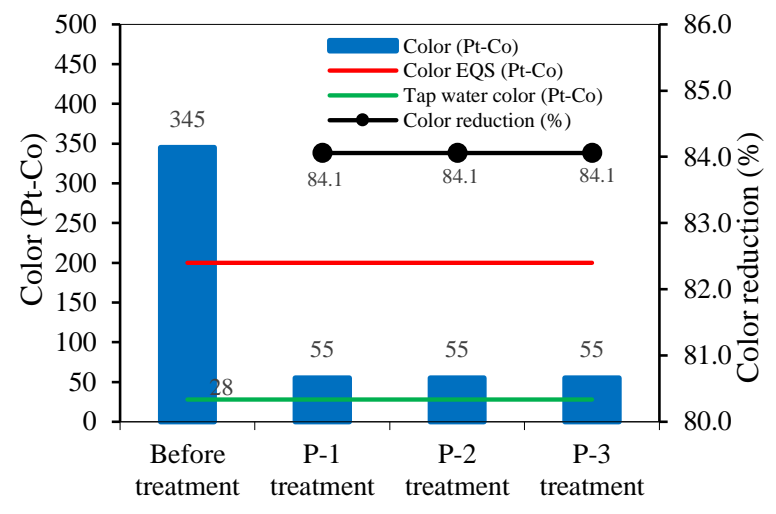

Wastewater

Figure 5. Color of wastewater before and after treatment

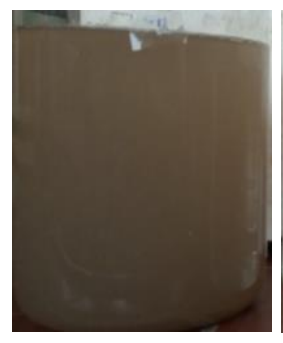

Untreated wastewater

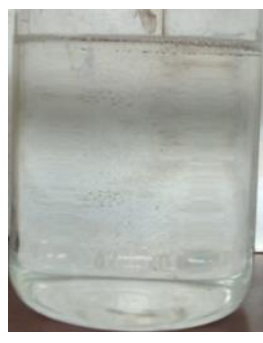

Treated wastewater P-2

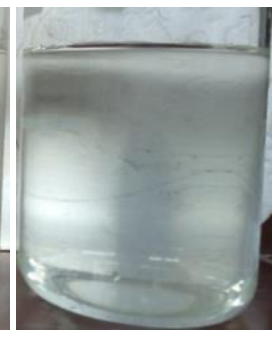

Tap water
Figure 6. Color of untreated wastewater and treated wastewater compared with tap water 
ions, as shown in Table 2. The quality of treated wastewater also complies with the quality standard requirements for the PSF industry which produces wastewater with a discharge of $100-1000 \mathrm{~m}^{3} /$ day (Table 2).

PSF industrial wastewater treatment variation with this optimum dose was better than a similar study reported by Zainuddin et al. [20] for wastewater treatment from recycling PET bottles washing process using $4 \mathrm{mg} / \mathrm{L}$ of $4 \% \mathrm{FeCl}$ coagulant solution and $0.8 \mathrm{mg} / \mathrm{L}$ of polyelectrolyte (PE) flocculant solution which could reduce COD by $58.28 \%$. Furthermore, the optimum wastewater treatment results from this study almost comparable with the results reported by Mehmood et al. [18] using 1,400 $\mathrm{mg} / \mathrm{L}$ of lime which could decreased the turbidity of wastewater by $94 \%$, decreased COD of wastewater by $86 \%$, decreased TSS of wastewater by $93 \%$, and decreased color of wastewater by $91.6 \%$.

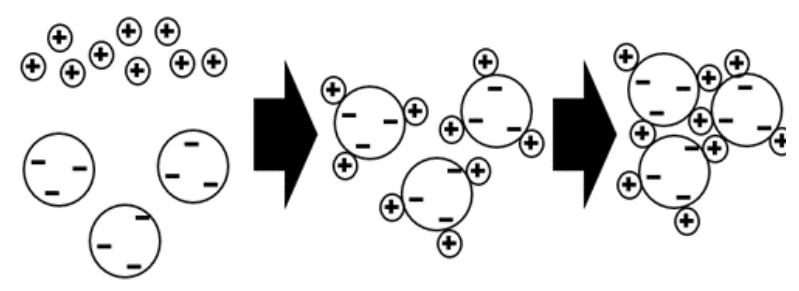

Figure 7. Phenomenon of coagulation $[11,16]$

Table 2. Quality of treated wastewater by treatment P-2

\begin{tabular}{|c|c|c|c|}
\hline No. & Parameter & Concentration & $\begin{array}{c}\text { Effluent Quality } \\
\text { Standards }\end{array}$ \\
\hline 1 & $\mathrm{BOD}_{5}, \mathrm{mg} / \mathrm{L}$ & 18.8 & 45 \\
\hline 2 & $\mathrm{COD}, \mathrm{mg} / \mathrm{L}$ & 87.9 & 125 \\
\hline 3 & $\mathrm{TSS}, \mathrm{mg} / \mathrm{L}$ & 7.4 & 40 \\
\hline 4 & Phenol, mg/L & 0.26 & 0.5 \\
\hline 5 & Chromium, mg/L & 0.05 & 1 \\
\hline 6 & $\begin{array}{l}\text { Ammonia }\left(\mathrm{NH}_{3^{-}}\right. \\
\mathrm{N}), \mathrm{mg} / \mathrm{L}\end{array}$ & 5.4 & 8 \\
\hline 7 & $\begin{array}{c}\text { Sulfide }\left(S^{2-}\right) \\
\mathrm{mg} / \mathrm{L}\end{array}$ & 0.06 & 0.3 \\
\hline 8 & $\begin{array}{c}\text { Oil and Grease, } \\
\text { mg/L }\end{array}$ & 1.06 & 3 \\
\hline 9 & $\mathrm{pH}$ & 7.1 & $6-9$ \\
\hline 10 & Color, Pt-Co & 55 & 200 \\
\hline 11 & $\begin{array}{c}\text { Discharge, } \\
\mathrm{m}^{3} / \text { day }\end{array}$ & $<100$ & $100-1000$ \\
\hline
\end{tabular}

\section{CONCLUSION}

$\mathrm{BOD}_{5}, \mathrm{COD}$, TSS, oil and grease, and color parameters from wastewater of PSF industry which using recycled PET bottle as raw materials, were not complied with the quality standard requirements. The wastewater needs to undergo a series of treatment before being discharged into the environment to avoid negative impact. Chemical treatment of PSF industry wastewater using $200 \mathrm{mg} / \mathrm{L}$ of $5 \%$ poly aluminum chloride (PAC) coagulant solution and $0.25 \mathrm{mg} / \mathrm{L}$ of $0.02 \%$ poly electrolyte (PE) flocculant solution could produce a treated wastewater complying with the effluent quality standard for textiles industry producing wastewater with a discharge of $<1000 \mathrm{~m}^{3} /$ day. Decreasing of wastewater pollutants subtances of PSF industry could be minimized its impact on the environment.

\section{REFERENCES}

1. Tiseo, I. Production of Polyethylene Terephthalate Bottles Worldwide from 2004 to 2021. 2020; Available from: www.statista.com.

2. Gupta, R., V.K. Shukla and P. Agarwal, 2019. Sustainable Transformation in Modest Fashion through "Rpet Technology" and "Dry-Dye" Process, Using Recycled Pet Plastic. International Journal of Recent Technology and Engineering, 8(3): 5415-5421. https://doi.org/10.35940/ijrte.A1432.098319

3. Marani, D., R. Ramadori, V. Renzi, C. Braguglia and A. Di Pinto, 2004. Improving Stp Performance by Lime Addition, in Enhancing Urban Environment by Environmental Upgrading and Restoration. Springer. p. 215-226. https://doi.org/10.1007/1-40202694-3 19.

4. Damanhuri, E. and T. Padmi, 2009. Current Situation of Waste Recycling in Indonesia, in 3r Policies for Southeast and East Asia. ERIA Research Project Report 2008-6-1. p. 23-52.

5. Kristina, H.J., A. Christiani and E. Jobiliong, 2018. The Prospects and Challenges of Plastic Bottle Waste Recycling in Indonesia. in IOP Conference Series: Earth and Environmental Science, pp: 012027. https://iopscience.iop.org

6. Sarioğlu, E. and H.K. Kaynak, 2017. Pet Bottle Recycling for Sustainable Textiles, in Polyester- Production, Characterization and Innovative Applications, N.O. Camlibel, Editor., IntechOpen. p. 9789535138815, http://dx.doi.org/10.5772/intechopen.72589.

7. Archna, A., V. Moses, S. Sagar, V. Shivraj and S. Chetan, 2016. A Review on Processing of Waste Pet (Polyethylene Terephthalate) Plastics. International Journal of Polymer Science and Engineering, 1(1-2): https://doi.org/10.37628/ijpse.v1i1$\underline{2.120}$

8. Jabłońska, B., P. Kiełbasa, M. Korenko and T. Dróżdż, 2019. Physical and Chemical Properties of Waste from Pet Bottles Washing as a Component of Solid Fuels. Energies, 12(11): 2197. https://doi.org/10.3390/en12112197

9. Irfan, M., T. Butt, N. Imtiaz, N. Abbas, R.A. Khan and A. Shafique, 2017. The Removal of Cod, Tss and Colour of Black Liquor by Coagulation-Flocculation Process at Optimized Ph, Settling and Dosing Rate. Arabian Journal of Chemistry, 10S2307-S2318. https://doi.org/10.1016/j.arabjc.2013.08.007

10. Kumar, P., T.T. Teng, S. Chand and K.L. Wasewar, 2011. Treatment of Paper and Pulp Mill Effluent by Coagulation. World Academy of Science, Engineering and Technology, 5(8):

11. Tantemsapya, N., W. Wirojanagud and S. Sakolchai, 2004. Removal of Color, Cod and Lignin of Pulp and Paper Wastewater Using Wood Ash. Songklanakarin Journal of Science and Technology, 26(1): 1-12.

12. Hubbe, M.A., J.R. Metts, D. Hermosilla, M.A. Blanco, L. Yerushalmi, F. Haghighat, P. Lindholm-Lehto, Z. Khodaparast, M. Kamali and A. Elliott, 2016. Wastewater Treatment and Reclamation: A Review of Pulp and Paper Industry Practices and Opportunities. BioResources, 11(3): 7953-8091.

13. Putri, A.S. and P. Soewondo, 2010. Optimizing Dye Removal from Textile Wastewater Using Two Stages Coagulation. Jurnal Teknik Lingkungan, 16(1): 10-20.

14. Ayeche, R., 2012. Treatment by Coagulation-Flocculation of Dairy Wastewater with the Residual Lime of National Algerian 
Industrial Gases Company (Nigc-Annaba). Energy procedia, 18: 147-156. https://doi.org/10.1016/j.egypro.2012.05.026

15. Yaser, A., T. Cassey, M. Hairul and A. Shazwan, 2014. Current Review on the Coagulation/Flocculation of Lignin Containing Wastewater. International Journal of Waste Resources, 4(3): 153159. https://doi.org/10.4172/2252-5211.1000153

16. Sahu, O. and P. Chaudhari, 2013. Review on Chemical Treatment of Industrial Waste Water. Journal of Applied Sciences and Environmental Management, 17(2): 241-257. https://doi.org/10.4314/jasem.v17i2.8

17. Semerjian, L. and G. Ayoub, 2003. High-Ph-Magnesium Coagulation-Flocculation in Wastewater Treatment. Advances in
Environmental
Research,
$7(2)$ :
389-403. https://doi.org/10.1016/S1093-0191(02)00009-6

18. Mehmood, K., S.K.U. Rehman, J. Wang, F. Farooq, Q. Mahmood, A.M. Jadoon, M.F. Javed and I. Ahmad, 2019. Treatment of Pulp and Paper Industrial Effluent Using Physicochemical Process for Recycling. $\quad$ Water, 11(11): 2393. https://doi.org/10.3390/w11112393
19. Sher, F., A. Malik and H. Liu, 2013. Industrial Polymer Effluent Treatment by Chemical Coagulation and Flocculation. Journal of Environmental Chemical Engineering, 1(4): 684-689. https://doi.org/10.1016/j.jece.2013.07.003

20. Zainuddin, N., M. Rosley, F. Anuar and N. Sarwani, 2019 Reduction of Chemical Oxygen Demand (Cod) Effluent of Plastic Recycling Processing Plant Using Ld Slag. International Journal of Recent Technology and Engineering, 8(4): 6750-6755. https://doi.org/10.35940/ijrte.D5217.118419

21. American Public Health Association (APHA), 2012. Standard Methods for the Examination of Water and Wastewater. Water Environment Federation.

22. Santos, A., B. Teixeira, J. Agnelli and S. Manrich, 2005. Characterization of Effluents through a Typical Plastic Recycling Process: An Evaluation of Cleaning Performance and Environmental Pollution. Resources, conservation and recycling, 45(2): 159-171. https://doi.org/10.1016/j.resconrec.2005.01.011

\section{COPYRIGHTS}

(C)2021 The author(s). This is an open access article distributed under the terms of the Creative Commons Attribution (CC BY 4.0), which permits unrestricted use, distribution, and reproduction in any medium, as long as the original authors and source are cited. No permission is required from the authors or the publishers.

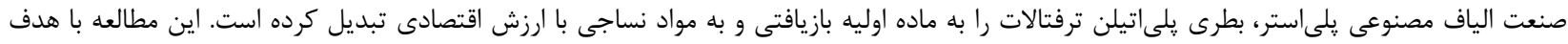

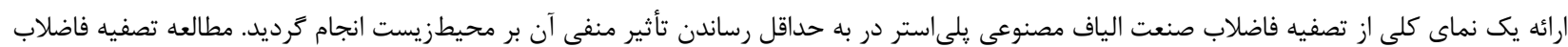

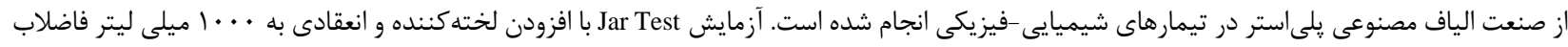

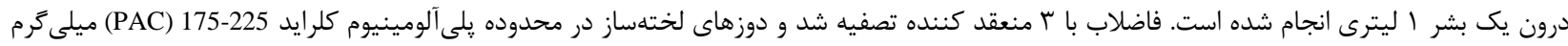

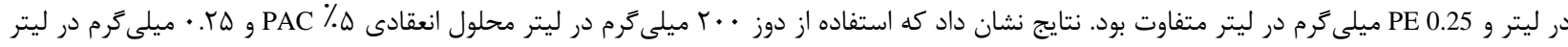

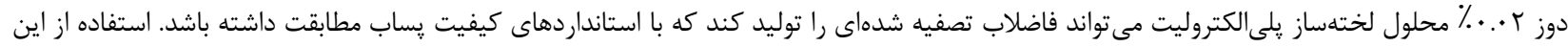

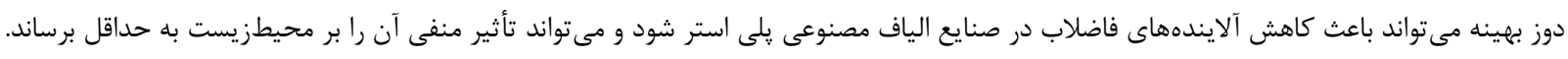

